\title{
PAGELARAN MAMACA DAN PROSES MENJADI MANUSIA MADURA
}

\author{
Panakajaya Hidayatullah ${ }^{1}$ \\ ${ }^{1}$ Fakultas IImu Budaya, Universitas Jember, Kampus Tegalboto, Jl. Kalimantan No.37, Sumbersari, Kec. \\ Sumbersari, Kabupaten Jember, Jawa Timur, Indonesia \\ ${ }^{(*)} \bowtie$ (e-mail) panakajaya.hidayatullah@gmail.com ${ }^{1}$
}

\begin{abstract}
Abstrak
Masyarakat Madura mewarisi tradisi sastra lisan yang sampai saat ini masih dipertahankan, yakni tradisi mamaca. Mamaca adalah salah satu seni tradisi yang hidup dalam masyarakat Madura sejak masuknya Islam ke Jawa dan Madura. Penelitian ini bertujuan untuk mengurai mengenai pagelaran mamaca sebagai proses dalam membentuk identitas sebagai manusia Madura dan bagaimana mereka memaknai kesenian mamaca lewat proses pergelarannya. Dalam penelitian ini digunakan pendekatan performace studies dengan menggunakan metode etnografi. Korpus penelitiannya ialah pagelaran mamaca pada masyarakat Sumenep Madura. Hasil penelitian menunjukkan bahwa bagi masyarakat Madura khususnya di Sumenep Madura, mamaca tidak hanya sekedar pagelaran seni semata namun sebuah proses untuk mengenali diri (Ngajhi Abâ'), mempelajari tatakrama (adhâb), internalisasi nilainilai Islam dan menjadi manusia Madura seutuhnya. Manusia Madura yang sopan, rendah hati, berbahasa halus, dan berserah diri. Perihal ini menarik untuk ditelaah, karena bertolak belakang dengan stereotype yang cenderung melekat pada masyarakat Madura sebagai masyarakat yang kasar, udik, suka berkelahi, dan keras kepala. Melalui pendekatan performance studies, pagelaran mamaca dapat ditafsir beberapa moda pertunjukannya (mode of performance) antara lain cara berpakaian yang menunjukkan simbol kehormatan dan relasi kuasanya, posisi pertunjukan, bentuk musikal yang lembut dan lambat, serta penggunaan beberapa perangkat pengeras suara yang mengingatkan akan nilai-nilai kehidupan dan sebagai simbol masyarakat komunal.
\end{abstract}

Kata kunci: tradisi lisan, mamaca, madura, pagelaran, sumenap

\begin{abstract}
The Madurese inherit the oral literary tradition which is still preserved, the mamaca tradition. Mamaca is one of the traditional arts that has lived in Madurese society since the entry of Islam into Java and Madura. This study aims to describe the mamaca performance as a process in shaping the identity as Madurese humans and how they interpret the mamaca art through the performance process. This research uses a performance studies approach using ethnographic methods. The research corpus is a mamaca performance in the Sumenep Madura community. The results showed that for the Madurese people, especially in Sumenep Madura, mamaca is not just an art performance but a process of selfidentification (ngajhi Abâ'), studying manners (adhâb), internalizing Islamic values and becoming a complete Madurese person. Madurese people are polite, humble, speak softly, and surrender. This subject is interesting to study, because it contradicts the stereotype that tends to cling to the Madurese community as a society that is rude, bumpy, quarrelsome, and stubborn. Through the performance studies approach, mamaca performances can be interpreted in several modes of performance, among others, how to dress that shows symbols of honor and power relations, performance positions, soft and slow musical forms, and the use of several loudspeakers reminding the values of the value of life and as a symbol of communal society.
\end{abstract}

Keywords: oral tradition, mamaca, madura, performance, sumenep

(c) (1) (2)

This work is licensed under a Creative Commons Attribution-ShareAlike 4.0 International License.

Copyright @ 2020 Birul Walidaini

Proses Artikel

Diterima 30-09-2020; Revisi 02-12-2020; Terbit Online 08-12-2020 


\section{Pendahuluan}

Masyarakat Madura di Sumenep menyimpan pelbagai warisan budaya yang berharga, beberapa yang masih bisa dirasakan hingga saat ini ialah warisan seni pertunjukan tradisinya. Ihwal ini menjadi suatu identitas budaya bangsa yang menjadi kebanggan dan diturunkan dari generasi ke generasi dalam suatu wilayah (Permanasari, Alis Triena; Setian, 2020: 60). Sebagai sebuah daerah yang wilayahnya merupakan bekas kekuasaan keraton Sumenep di masa silam, di daerah ini masih terlihat subur beberapa seni pertunjukan tradisi khas keraton. Ahimsa-Putra (2015, p. 3) menyebut wilayah tradisi keraton ini sebagai tradisi ageng (great tradition) dimana corak kebudayaannya banyak diwarnai oleh kebudayaan keraton/istana yang seringkali disebut sebagai kebudayaan yang 'adiluhung'. Salah satu corak seni tradisi ageng yang masih lestari ialah seni mamaca. Mamaca adalah seni tradisi lisan yang hidup di sebagian besar masyarakat Madura baik di pulau maupun di daerah migrasi.

Bentuk kesenian mamaca sederhananya ialah menyerupai kesenian macopat di Jawa, berasal dari teks kitab yang ditulis dengan aksara arab, berbahasa jawa yang dinyanyikan/ditembangkan menggunakan lagu tertentu. Bedanya di Madura tembang tersebut kemudian ditafsir ke dalam bahasa Madura oleh tokang tegghes. Dalam kehidupan masyarakat Madura, kesenian mamaca memiliki peran yang cukup signifikan dalam membentuk karakter masyarakat Madura. la menjadi sumber pengetahuan yang tidak hanya dibaca oleh pelakunya tetapi juga diamalkan oleh setiap masyarakat Madura yang mengalami proses belajar mamaca dalam kehidupan sehari-hari. Seperti halnya seni musik, bentuk seni pertunjukan mamaca juga memiliki fungsi dalam mempresentasikan pengalaman, kehidupan sehari-hari serta kondisi sosial dimana seni tersebut diaktualisasikan (Walidaini, 2020: 95)

Sejauh ini tidak banyak yang tahu tentang bagaimana cara masyarakat Madura membangun karakter masyarakatnya melalui media kearifan lokalnya seperti misalnya lewat seni mamaca. Seringkali masyarakat Madura hanya disoroti seputar stereotip negatifnya yang terkesan semena-mena, sehingga yang melekat hanyalah ingatan tentang masyarkat yang keras, kasar dan suka berkelahi. Kurangnya referensi mengenai kajian masyarakat Madura yang komprehensif memperbesar gap pengetahuan tentangnya, sehingga dirasa perlu untuk dilakukan kajian yang mendalam melalui pelbagai perspektif. Sorotan dalam tulisan ini akan mengurai pelbagai permasalahan perihal, bagaimana masyarakat Madura khususnya di Sumenep memaknai kesenian mamaca lewat proses belajar mamaca?; bagaimana mamaca dipraktekkan sebagai proses mengenali diri, mempelajari tatakrama dan menjadi manusia Madura? Guna mengurai permasalahan di atas, akan digunakan pendekatan performance studies dengan metode etnografi partisipatoris yang mewajibkan peneliti untuk masuk dalam aktivitas kebudayaan masyarakat yang diteliti. Proses penggalian makna tidak lagi difokuskan pada penafsiran teks, dan narasi yang didapatkan dari wawancara namun difokuskan pada peristiwa pergelarannya. Sebagaimana pendapat Simatupang (Simatupang, 2019, p. 16), bahwa "melalui peristiwa pergelaran, makna paling utuh dari mamaca sedang diartikulasikan, diciptakan dan diciptakan ulang pada saat yang bersamaan". Pendekatan ini digunakan untuk memperkaya khasanah keilmuan khususnya tentang mamaca, karena kebanyakan penelitian sebelumnya tentang mamaca masih berkutat pada penafsiran teks, penggalian sejarah, dan pembacaan teks-teks pertunjukan mamaca sebagai representasi simbolik. 
Adapun penelitian sebelumnya mengenai kesenian mamaca ialah milik Rifa'i (Ahmad, 2017) berjudul "sepenggal Kearifan Bondowoso: Tradisi Mamaca Madura Parry - Lord's Perspective", kajian ini berfokus pada kajian bentuk pertunjukan dan penafsiran makna melalui analisis tradisi lisan. Perbedaan kajian Rifa'i dengan kajian ini ialah pada pendekatan dan metode yang digunakan, pada penelitian ini digunakan pendekatan performance studies yang tafsirnya tidak terbatas pada teks namun pada peristiwa pergelarannya. Penelitian ini diharapkan dapat membuka cakrawala pengetahuan baru tentang pagelaran seni mamaca khususnya yang berkaitan dengan kehidupan masyarakat Madura di Sumenep.

\section{Metode}

Penelitian ini adalah penelitian kualitatif, menggunakan pendekatan Performance Studies dengan metode etnografi partisipatoris. Korpus penelitiannya adalah masyarakat Madura di Sumenep Madura, secara spesifik akan menyoroti pagelaran mamaca pada kelompok arisan di Desa Kebundadap Barat, Kecamatan Saronggi, Kabupaten Sumenep Madura. Adapaun pengambilan data dilakukan secara langsung melalui pengamatan lapangan yang dicatat dan direkam menggunakan media perekam audio-visual berupa digital voice recorder dan kamera DSLR. Sebagai data pelengkap akan dilakukan wawancara ke beberapa informan kunci yakni pelaku mamaca, tokoh mamaca, seniman, budayawan, dan masyarakat sekitar.

Data yang telah terkumpul kemudian diklasifikasi berdasarkan jenis datanya. Selanjutnya dilakukan reduksi data yang disesuaikan dengan kebutuhan penelitian. Hasil dari reduksi data kemudian dianalisis dan ditafsir menggunakan pelbagai teori seni pertunjukan dan kajian budaya.

\section{Hasil}

\section{Menjadi Manusia Madura Melalui Mamaca}

Di sebuah teras rumah yang cukup luas, beberapa orang laki-laki berpakaian sarung, kemeja dan kopiah sedang sibuk mempersiapkan perlengkapan, ada yang menurunkan seperangkat alat gamelan dari motor Tossa (sepeda motor roda tiga dengan gerobak di belakangnya), ada yang sedang memasang loudspeaker (TOA) ke tiang bambu sepanjang 5 meter, ada yang menggelar tikar, ada yang menyiapkan amplifier untuk kebutuhan pengeras suara, sementara yang lain turut membantu dan mengambil peran sembari sesekali mengobrol dan bergurau. Saya disambut oleh tuan rumah dengan ramah dan menceritakan bahwa kompolan mamaca yang dipergelarkan di rumahnya malam ini adalah gabungan dari kompolan mamaca Bunga Arum dari Aeng Tong-Tong dan kompolan mamaca Seni Rahayu dari Kebundadap Barat. Mereka rutin mengadakan pergelaran mamaca setiap minggu secara bergiliran (anjangsana). Tidak lama kemudian, sekira pukul 21.00 WIB, mereka menyusun formasi pertunjukan, para pemain gamelan berada di teras bawah menghadap ke rumah, sementara para pelaku mamaca dan anggota lainnya duduk di teras atas saling berhadap-hadapan (catatan etnografi, tanggal 30 Juli 2019 di Kebundadap Barat, Saronggi, Sumenep).

Catatan etnografi di atas menggambarkan tentang situasi dan konteks kompolan masyarakat Madura di desa Kebundadap Barat, Saronggi, Sumenep yang melaksanakan pergelaran mamaca. Pada catatan di atas dapat dilihat bagaimana kompolan mamaca menjadi ruang untuk saling bersilaturrahmi, bertemunya para pelaku seni tradisi dan penikmatnya. Kompolan mamaca mampu merekatkan masyarakat lintas desa di Sumenep, 
mereka terhubung antara satu desa dengan desa yang lainnya melalui kesenian mamaca. Perihal ini dapat dijelaskan dari semakin berkurangnya para peminat mamaca di Sumenep, jika dahulu setiap desa bisa memiliki 1-2 kompolan mamaca, maka kondisi saat ini semakin buruk sehingga membuat kompolan mamaca lintas daerah bergabung menjadi satu (Acik, Komunikasi Pribadi, 30 Juli 2019). Tujuannya supaya memunculkan semangat kebersamaan, saling memotivasi dan semakin memperkuat tekad dalam mengembangkan seni tradisi mamaca. Mamaca dalam hal ini dapat dibaca sebagai proses masyarakat Madura menjalin relasi sosial dengan sesamanya, ia mendorong terciptanya kehidupan sosial yang harmonis, saling gotong-royong dan mandiri, jika dilihat dari semangatnya mengembangkan kesenian tradisi melalui gerakan kolaboratif. Kesadaran mereka terhadap pentingnya mengembangkan nilai-nilai budaya dalam seni tradisi membuat kompolan mamaca ini tetap hidup dan berjalan sampai hari ini, meskipun di ruang dan waktu yang sama mereka sedang berhadapan dengan modernisasi yang semakin hari semakin mengikis eksistensi seni tradisi yang sedang mereka geluti.

Pada pukul 21.00, perangkat gamelan mulai ditabuh, mereka memainkan beberapa gending pembuka sebelum acara mamaca dimulai. Acara itu disiarkan melalui loudspeaker ke seluruh penjuru desa, sehingga orang yang bukan anggota kompolan mamaca pun masih bisa menyimak jalannya acara. Acara dibuka oleh Pak Jumawar (70an tahun), selain bertugas sebagai MC beliau juga memiliki tugas sebagai tokang tegghes. Salam pembuka yang dibacakan oleh Pak Jumawar dibacakan dengan lantang (jelas) namun menggunakan intonasi yang halus, menggunakan tingkat bahasa yang tinggi, dan pembawaan yang tenang. Dalam sambutannya, ia menyampaikan selamat datang kepada semua tamu anggota kompolan, dilanjutkan dengan mengenalkan kompolan mamaca Seni Rahayu dan Bunga Arum kepada khalayak, serta mengucapkan terima kasih kepada tuan rumah.

Acara berlanjut pada pembacaan mamaca, cerita yang diangkat pada pergelaran malam itu adalah kisah Sang Dewi Juhar Manik. Bersama iringan gamelan yang lamat-lamat, Pak llyas (70an tahun) memohon ijin pada sesama anggota dengan cara hormat sungkem untuk memulai membaca kitab. Kitab mamaca diletakkan di atas bantal yang posisinya berada di antara tokang maca dan tokang tegghes. la memulai membaca kitab dengan suara yang lembut, meliuk-liuk hingga mencapai notasi-notasi tinggi, namun tetap dengan pembawaan yang kalem dan tenang. Lagu yang ditembangkan pertama kali ialah kembhâng artatè patet 9. Alur penyajian dimulai dari tokang maca membaca 1-2 ayat di kitab, di tengah-tengah pembacaan, suling mengikuti alur melodinya dan menuntun tokang maca membentuk pola melodi sesuai tembangnya. Pada kalimat akhir ayat, suara gamelan dibunyikan untuk menandai pergantian peran tokang maca kepada tokang tegghes. Setelah tokang maca selesai membaca, lalu Pak Jumawar sebagai tokang tegghes mengambil alih peran dengan menginterpretasi ayat yang dibacakan tadi menggunakan bahasa Madura tingkat tinggi (halus). Penafsiran tidak dibaca secara datar tetapi dibacakan dengan gaya bercerita layaknya seorang dalang. Pola ini berulang sampai 3-5 kali putaran, kemudian istirahat dan jeda tersebut diisi oleh permainan gending gamelan. Ihwal yang menarik ketika teks mamaca itu dibacakan, tidak ada satupun orang yang berbicara, semuamya menyimak, meresapi dan masuk ke dalam cerita tersebut. Walaupun tidak ada aturan tertulis maupun yang dibacakan oleh MC di awal pergelaran tetapi etika pertunjukan 
seperti tidak berbicara saat pergelaran itu dilakukan dengan sungguh-sungguh oleh para anggota kompolan. Modus partisipatoris terasa nampak pada beberapa putaran penyajian terakhir, dimana beberapa orang penabuh gamelan diminta untuk bergantian membacakan teks kitab mamaca. (catatan etnografi, tanggal 30 Juli 2019 di Kebundadap Barat, Saronggi, Sumenep).

Berdasarkan catatan etnografi di atas memberikan ilustrasi tentang jalannya penyajian pergelaran pada konteks kompolan mamaca. Ada beberapa poin menarik yang dapat diuraikan dari penyajian pergelaran pada kompolan mamaca di atas. Pertama perihal tentang bagaimana urusan adhâb (tatakrama dan sopan santun) itu diwujudkan dalam peristiwa pergelaran. Rangkaian peristiwa pergelaran mamaca di atas memberikan gambaran tentang bagaimana seharusnya tatakrama dan sopan santun diaktualisasikan dalam kehidupan seharihari. Ihwal ini ditunjukkan melalui penggunaan tingkat bahasa yang tinggi (halus) dalam pertunjukan, intonasi vokal yang lembut dan tenang, sikap apresiatif, sikap rendah hati dan saling menghormati. Sikap apresiatif ditunjukkan oleh seluruh para anggota kompolan yang menyimak jalannya sajian pertunjukan tanpa berbicara, bahkan mereka menyimaknya dengan seksama. Sikap rendah hati tercermin pada sikap para pelaku mamaca, yang bersedia membagi perannya sebagai tokang maca kepada para pemain gamelan dan anggota kompolan mamaca yang lain. Sikap rendah hati juga ditunjukkan oleh sikap hormat sungkem yang dilakukan oleh tokang maca kepada tokang tegghes dan anggota lainnya

Hal ini sejalan dengan apa yang dikatakan oleh $\mathrm{KH}$ Ismail dan Ilyas, bahwa hal yang penting dari belajar mamaca adalah belajar menjadi mannusia yang bijaksana, mengedepankan tatakrama, akhlak, dan sopan santun (KH Ismail dan Ilyas, Komunikasi Pribadi, 30 Juli 2019). Internalisasi nilai-nilai edukasi semacam ini bahkan sudah diterapkan sejak usia dini, ketika seorang anak belajar mamaca kepada seorang guru di langghâr. Maka dapat dikatakan bahwa mamaca adalah ruang dimana nilai-nilai tentang adhâb diaktualisasikan terus menerus, mamaca adalah proses pembentukan karakter menjadi manusia yang berakhlak, memiliki tatakrama dan sopan santun yang baik.

Ihwal kedua, mamaca dapat dibaca sebagai proses seseorang belajar mengendalikan dirinya, mengendalikan hawa nafsunya, dan menjalani kehidupan dunia dengan penuh kehati-hatian. Perihal itu tergambar pada peristiwa pergelaran mamaca, dimana bentuk penyajian musik cenderung dimainkan dengan karakter yang lembut, halus, dan bertempo lambat. Perlu dijelaskan bahwa dalam kebudayaan Madura, penyajian gamelan tidak selamanya dimainkan dengan karakter lembut dan halus. Di beberapa pertunjukan justru gamelan dimainkan dengan karakter yang kasar, keras bahkan 'meledak-ledak' sebegaimana pada pertunjukan tabbhuwân ketoprak dan luddrok. Jika dilihat dari latar belakang pemain gamelan di pergelaran mamaca, rata-rata mereka merupakan 'mantan' pemain tabbhuwân ketoprak dan luddrok (Juarda, komunikasi pribadi, 30 Juli 2019). Artinya mereka sedang memainkan sesuatu yang 'tidak biasa' dari biasanya. Kebiasaan mereka dalam memainkan gamelan dengan cara yang atraktif dan 'meledak-ledak' dalam pertunjukan tabbhuwân harus mereka redam pada pergelaran mamaca. Meredam emosi dan menuangkan dalam sajian musik yang halus, lembut dan bertempo lambat adalah proses yang lebih sulit dari pada meluapkan emosinya pada musik yang keras. Dalam konteks ini dapat ditafsir bahwa peristiwa mamaca merupakan proses pengendalian diri seseorang. 
Bagi anggota yang lain, proses pengendalian diri dapat dilihat dari bagaimana mereka harus berusaha tenang dan sabar dalam situasi pertunjukan yang cukup lama dan panjang. Mereka dituntut untuk selalu menyimak jalannya cerita tanpa berbicara, belum lagi mereka harus melawan rasa ngantuk dan bosan mengingat durasi pertunjukan mamaca cukup lama dan dimainkan sepanjang malam.

Ihwal ketiga, mamaca merupakan sarana bagi seseorang untuk belajar mengenali dirinya (ngajhi abâ'). Proses mengenal diri tidak bisa didapatkan dari sekedar pemahaman saja, namun dibutuhkan proses pendalaman batin, perenungan mendalam dan pencerahan pemikiran. Peristiwa mamaca memberikan jalan untuk mengalami pengalaman spiritual bagi pelaku dan penikmatnya. Di dalam pergelaran mamaca, mereka dihadapkan dengan pelbagai kisah-kisah yang mampu mengantarkan mereka menuju pendalaman batin. Dalam pergelaran mamaca mereka dihadapkan terus menerus dengan persoalan-persoalan realitas yang direpresentasikan melalui pergelaran, ihwal ini menjadi semacam wahana katarsis bagi para penikmatnya. Kisah-kisah yang diangkat dalam pergelaran mamaca umumnya adalah kisah yang cukup berat untuk dicerna masyarakat awam, dibutuhkan perenungan mendalam, dan ketenangan jiwa. Sebagai contohnya kisah yang diambil dari kitab Al Hikam, dalam kitab ini berisi tentang pergulatan pemikiran tentang ilmu tasawuf, tentang bagaimana seseorang harus memaknai 'dirinya yang sejati', tentang hubungan seorang hamba kepada Tuhannya.

KH Ismail, sebagai seorang praktisi mamaca dan seorang ulama yang biasa memberikan ceramah agama kepada masyarakat mengakui bahwa kandungan makna yang ada dalam kitab mamaca dianggap lebih berbobot dan berat jika dibandingkan dengan materi-materi dakwah yang seringkali ia sampaikan (Ismail, Komunikasi Pribadi, 30 Juli 2019). Lebih lanjut, $\mathrm{KH}$ Ismail memberikan pernyataan bahwa, dalam syiar agama Islam, pergelaran mamaca dianggap lebih ideal karena penyajian ceritanya runtut dan detail dibanding dengan penyajian ceramah yang terkadang tidak runtut, dan acap kali dibumbui banyak kepentingan politis. Dalam pergelaran mamaca, tidak mungkin hal itu bisa terjadi, karena semuanya bersumber pada teks yang jelas.

Jika ditinjau dari format penyajian pergelarannya, mamaca juga dapat dibaca sebagai simbol kehormatan bagi masyarakat Madura. Dilihat dari posisi pertunjukan, ada pembagian peran yang berbeda pada kompolan mamaca. Para pemain gamelan menempati posisi di teras bawah, sedangkan para pelaku mamaca (tokang maca dan tokang tegghes) menempati posisi di teras atas. Posisi ini menunjukkan struktur hirarkis dalam pergelaran mamaca dimana pelaku mamaca dibaca sebagai aktor yang memiliki posisi dominan dalam kompolan mamaca dibanding para pemain gamelan. Selain posisi pertunjukan, struktur hirarkis antara pemain gamelan dan pelaku mamaca juga dapat dilihat dari cara berpakaian (kostum) para pelakunya. Pemain gamelan dan para anggota kompolan mamaca menggunakan kostum yang hampir sama yakni pakaian kemeja (hem dan batik), kopiah, dan sarung, sedangkan pelaku mamaca (tokang maca dan tokang tegghes) menggunakan kemeja yang dilengkapi dengan jas berwarna hitam dan abu-abu, kopiah dan sarung. 


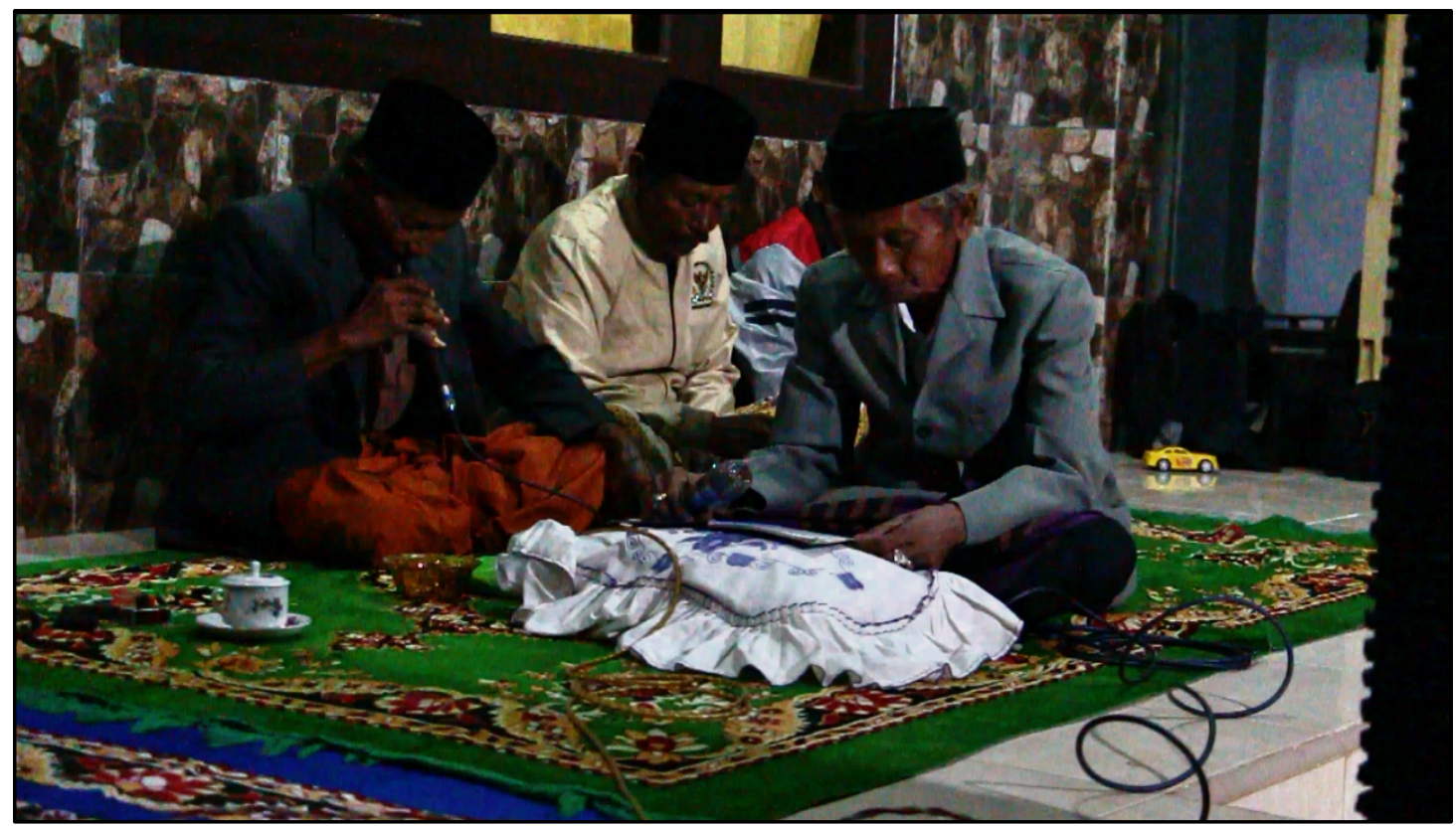

Gambar 1. Tokang maca dan tokang tegghes di teras atas mengenakan pakaian jas. Sumber: Dokumentasi Pribadi

Penggunaan jas menjadi pembeda yang identik antara siapa yang pelaku mamaca, siapa yang penikmat, dan siapa yang pemain gamelan. Pada pergelaran kompolan mamaca, pelaku mamaca dianggap memiliki ilmu dan pengetahuan yang lebih tinggi di antara yang lainnya, maka secara kultural mereka harus dihormati. Relasi kekuasaan yang dapat dibaca melalui pergelaran kompolan mamaca ini sebetulnya adalah bentuk pengaruh dari feodalisme Jawa yang juga berkembang di Madura seturut dengan eksistensi keraton Sumenep. Mamaca adalah bagian dari warisan seni keraton yang turut serta membawa aspek cara berperilaku seperti orang keraton.

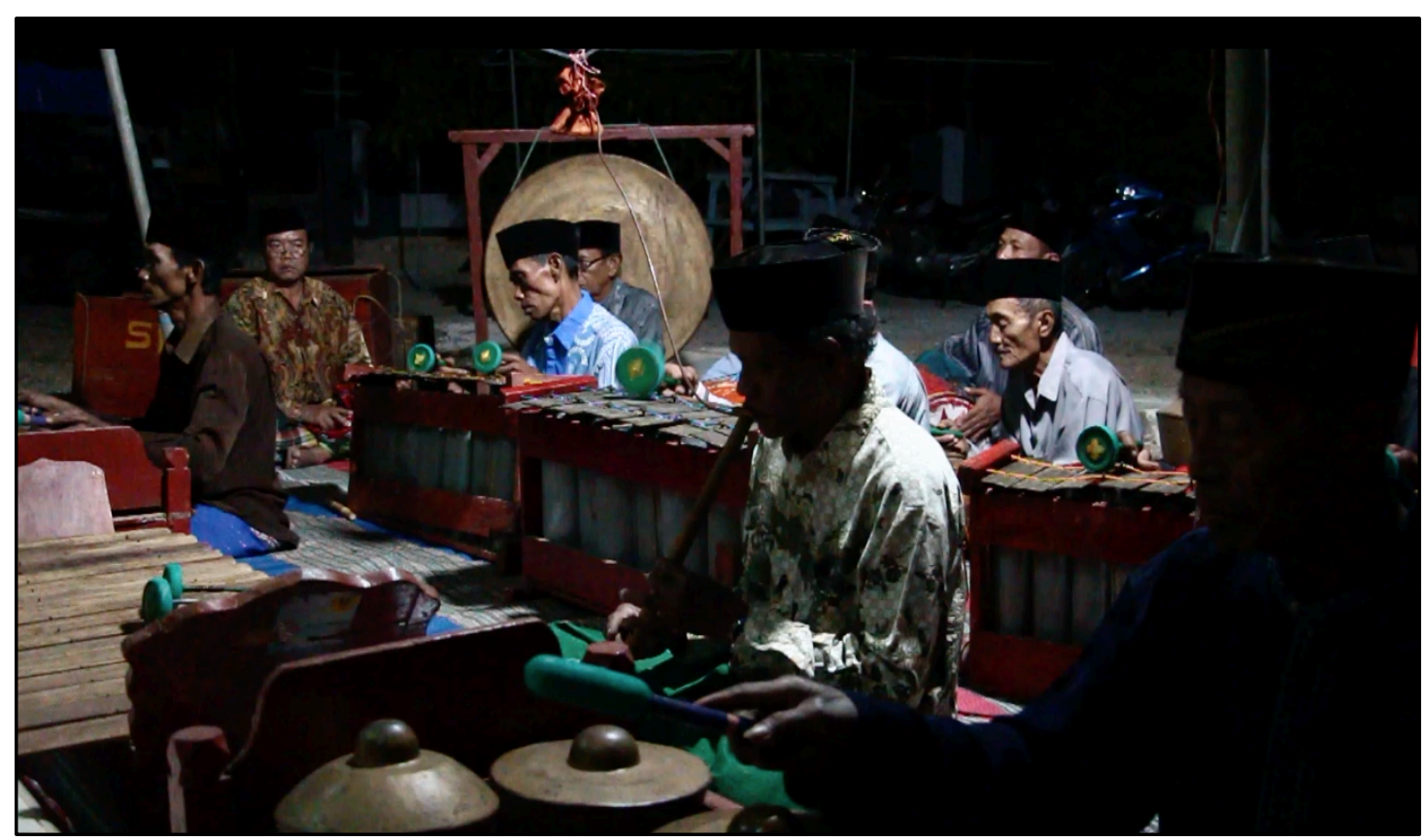

Gambar 2. Pemain gamelan di teras bawah menggunakan kemeja, kopiah, dan sarung Sumber: Dokumentasi Pribadi 
Ihwal keempat, mamaca dapat dibaca sebagai moda syiar Islam. Sebagaimana fungsi syiar yang harus dipublikasikan ke khalayak luas, mamaca secara konsisten masih menggunakan metode syiar yang demikian. Alih-alih hanya mengeksklusifkan diri pada kelompok kompolan mamaca saja, mereka justru membuka metode pertunjukan yang inklusif, yang terbuka dan dapat dinikmati oleh semua masyarakat di lingkungan sekitarnya. Terlihat dari bagaimana setiap pergelaran mamaca itu dipublikasikan melalui perangkat speaker (TOA) yang dipasang di atas tiang bambu setinggi 5 meter dan diamplifikasi supaya terdengar hingga ke seluruh pelosok desa. Dalam konteks ini, pagelaran mamaca memiliki fungsi untuk 'mengingatkan akan nilai-nilai kehidupan' kepada masyarakat. Penggunaan speaker dan publikasi yang masif ke seluruh penjuru desa juga dapat dibaca bahwa masyarakat Madura sejatinya adalah masyarakat yang komunal dan terbuka.

\section{Pembahasan}

\section{Mamaca Di Sumenep Madura}

Sumenep adalah salah satu kabupaten di pulau Madura yang wilayahnya terletak di ujung Timur, berbatasan dengan Kabupaten Pamekasan di sebelah Barat, Selat Madura di sebelah Selatan, Laut Jawa di sebelah Utara dan Laut Flores di sebelah Timur. Secara geografis, wilayah Kabupaten Sumenep terdiri atas wilayah daratan dan wilayah kepulauan. Masyarakat Sumenep didominasi oleh masyarakat etnik Madura, namun perlu dijelaskan bahwa masyarakat etnik Madura yang tersebar di pulau Madura tidak tunggal. Masyarkaat Madura adalah masyarakat yang beragam dan memiliki corak kebudayaan yang berbeda antara daerah satu dengan daerah lainnya. Ditinjau dari aspek sosiolinguistik, masyarakat Madura terbagi atas dua bagian yaitu penutur dengan menggunakan 1) dialek Madhurâ Bârâ' (Madura Barat) dan 2) dialek Madhuâ Tèmor (Madura Timur). Dialek Madura Barat umumnya digunakan oleh masyarakat Madura di wilayah Kabupaten Bangkalan, Sampang, Pamekasan, dan beberapa kecamatan di Kabupaten Sumenep yang berbatasan dengan Kabupaten Pamekasan seperti Parenduan (Selatan), Gulukguluk (Tengah), Pasongsongan (Utara). Sedangkan di luar pulau Madura dialek Madura Barat digunakan di Kabupaten Gresik, Surabaya, Pasuruan, Probolinggo, Jember dan Bondowoso. Dialek Madura Timur hanya digunakan di wilayah Kabupaten Sumenep, sedangkan di luar pulau Madura digunakan di Kabupaten Situbondo dan sebagaian Kabupaten Banyuwangi (Sofyan, 2009, p. 41). Data mengenai aspek kebahasaan yang diuraikan melalui pembacaan sosiolinguistik sejalan dengan corak kebudayaannya. Masyarakat Madura di Sumenep memiliki karakteristik budaya yang berbeda dengan wilayah lain di pulau Madura.

Dalam pandangan kultural, wilayah Sumenep seringkali dianggap dan diyakini sebagai wilayah sentral di pulau Madura. Pandangan tersebut merujuk pada kekuatan dan eksistensi keraton Songenep di masa lampau. Secara geografis, wilayah keraton Songenep berada di wilayah Kabupaten Sumenep. Seperti halnya kota Yogyakarta dan Solo di Jawa, Kabupaten Sumenep juga memiliki peran dan posisi yang sama pentingnya secara kultural, yakni menjadi pusat dan poros kebudayaan Madura. Perihal ini dapat dilihat dari tingkat penggunaan bahasa masyarakat di wilayah Sumenep yang memiliki kecenderungan berbahasa lebih halus dibanding wilayah Madura lainnya. Selain itu, ragam kesenian yang memiliki corak kesenian keraton dan berkarakter halus di wilayah ini merepresentasikan alam pikir dan tingkat kebudayaan khas masyarakat yang dekat dengan keraton. Sebagaimana yang dijelaskan oleh 
Retsikas, "semakin dekat kedudukannya dengan keraton dan sultan, maka semakin tinggi derajatnya serta derajat 'ke-halus-an' yang dicapai seseorang (Retsikas, 2007, p. 191).

Masyarakat Madura khususnya di Sumenep lekat dengan kebudayaan Islam, bahkan bisa dikatakan bahwa Islam merupakan karakter budaya masyarakat Madura di Sumenep. Pandangan hidup orang Madura tidak dapat dilepaskan dari nilai-nilai Islam (Wiyata, 2013, p. 3). Islam menjadi bagian yang tidak terpisahkan dari proses berkebudayaan masyarakat Madura baik yang tinggal di pulau Madura maupun yang telah bermigrasi ke luar pulau Madura. Menurut Wiyata (2013, p. 3) merupakan suatu fakta sosiologis tak terbantahkan bahwa hampir seluruh masyarakat Madura adalah penganut agama Islam. Islam sebagai pandangan hidup masyarakat Madura menjadi dasar pedoman dan landasan hidup bagi setiap orang Madura guna menjalankan kehidupan dan kebudayaannya, maka ketaatan terhadap agama Islam merupakan sebuah jalan penjatidirian penting bagi orang Madura. Dalam keseharian, simbol-simbol Islam dipresentasikan melalui pembawaan di ranah sosial seperti ciri khas pakaian mereka yaitu sampèr (kain panjang), kebaya dan burgo' (kerudung) bagi perempuan, sarong (sarung) dan songko' (kopiah atau peci) bagi laki-laki (Rifai, 2007, p. 446). Selain dalam aspek keseharian, simbol Islam juga kerap muncul di hampir semua ritual tradisinya seperti ritual petik laut, ritual memanggil hujan, dan ritual kesuburan (Lihat, Bouvier, 2002, p. 179; Hidayatullah, 2015); keseniannya musiknya seperti hadrah, gambus, syi'ir dan tembhang (Yoandinas, Hidayatullah, Farhan, Imron, \& Martiningsih, 2020); serta aktivitas kebudayaan lainnya seperti peringatan maulid Nabi, Isra' Mi'raj, selamatan dalam siklus hidup manusia, pernikahan, dan lainnya.

Guna mengetahui pokok-pokok pikiran orang Madura khususnya mengenai relasinya dengan agama Islam, akan dijelaskan tentang pandangan orang Madura terhadap sosok figur dalam budayanya. Ada sosok figur dalam masyarakat Madura yang dihormati dan menjadi tauladan dalam kehidupan, termanifestasi dalam ungkapan bhuppa', bhabhu', ghuru, rato.

Figur pertama dan kedua ialah bhuppa' (ayah) dan bhabhu' (ibu) yaitu orang tua. Kepatuhan terhadap orang tua adalah bentuk keteladanan yang paling utama dan tidak dapat ditawar-tawar (Wiyata, 2013, p. 31). Baik dalam agama maupun dalam tradisi, kepatuhan terhadap orang tua adalah sesuatu yang paling diutamakan dalam kehidupan seorang anak Madura.

Figur ketiga yaitu ghuru (guru), guru dalam pandangan masyarakat Madura adalah guru yang memiliki peran dan fungsi pada tataran moralitas dan masalah-masalah ukhrowi (morality and sacred world), maka kepatuhan orang Madura sebagai penganut agama Islam yang taat tentu saja tidak dapat dibantah (Wiyata, 2013, p. 31). Figur ghuru yang dimaksud adalah sosok kiai dan tokoh agama (ulama) yang memiliki pengaruh dalam wilayah kebudayaan masyarkat Madura. Kiai dalam pandangan masyarakat Madura ialah sosok yang sangat dihormati karena dianggap dapat mengantarkan masyarakat menuju jalan yang lurus, dan membimbing menjadi manusia yang bijak. Dalam wilayah kebudayaan Madura, kiai tidak hanya bertugas mengajari mengaji (morok) tetapi seringkali menjadi pembimbing masyarkaat dalam banyak hal termasuk membantu masalah-masalah duniawi. Tidak heran jika kiai selalu menjadi tempat terakhir dalam memecahkan segala masalah dan musibah bagi masyarakat Madura yang sedang dirundung masalah, baik masalah pertanian, perikanan, rumah tangga, hutang-piutang, permohonan nama anak, mencari hari baik dan lainnya. Alih-alih hanya menjadi guru mengaji untuk para santrinya, kebanyakan kiai di lingkungan masyarakat Madura memposisikan dirinya sebagai pendamping dan pembimbing masyarkat (Hidayatullah, 2018b). Pandangan ini yang kemudian membuat masyarakat Madura lebih 
mempercayakan pendidikan anaknya kepada sosok kiai di dalam pesantren dibanding sekolah-sekolah formal. Bagi masyarakat Madura pendidikan pesantren adalah benteng terakhir untuk menyelamatkan akhlak seorang anak Madura di tengah-tengah derasnya arus modernisasi yang semikin hari semakin meresahkan.

Figur keempat (terakhir) yaitu figur rato. Figur rato dalam kebudayaan Madura ialah pemimpin formal atau biasa disebut birokrasi. Figur rato adalah suatu achievement status yang persyaratannya bukan faktor genealogis melainkan semata-mata karena faktor achievement (Wiyata, 2013, p. 34). Figur rato dalam masyarakat Madura dapat mewujud dalam sosok patènggi/kalèbun (kepala desa), Camat, Bupati dan Presiden. Pandangan atas keempat sosok figur ini pada akhirnya turut mempengaruhi sikap dan karakter masyarakat Madura.

Kentalnya budaya Islam juga tercermin pada suburnya tradisi pesantren di Sumenep Madura. Eksistensi pesantren di lingkungan masyarakat Madura dipengaruhi oleh pandangan hidup mereka, menitikberatkan pada pentingnya menjalani proses pendidikan Islam sejak dini. Dalam hal pendidikan, masyarakat Madura mempunyai pelbagai macam proses pembelajaran agama Islam, ada yang formal dan ada yang informal. Dalam wilayah pendidikan formal, terdapat lembaga pendidikan seperti sekolah madrasah hingga pondok pesantren, sedangkan dalam wilayah informal masyarakat Madura melaksanakan tradisi belajar-mengajar di langghâr (mushalla).

Seperti yang telah dijelaskan sebelumnya perihal pentingnya mengenyam pendidikan Islam dalam kehidupan masyarkat Madura, ihwal ini juga terwujud dalam penataan struktur rumah tanèyan lanjhâng dan budaya mangaji di langghâr. Masyarkaat Madura memiliki pola pemukiman yang khas yang dinamakan tanèyan lanjhâng. Dalam struktur pemukiman tersebut langghâr (mushalla) menjadi bangunan yang penting bahkan utama yang diletakkan di sisi bagian Barat tanèyang lanjhâng. Keberadaan langghâr dalam setiap pemukiman menjadi pusat segala aktifitas pendidikan bagi setiap keluarga Madura. Langghâr menjadi pusat pembelajaran pendidikan Islam yang dilakukan setiap malam, umumnya berlangsung dari waktu salat maghrib hingga salat isya. Setiap anak Madura diwajibkan untuk mengikuti proses pembelajaran mengaji di langghâr, perihal ini sudah menjadi budaya yang khas di lingkungan masyarakat Madura.

Di Sumenep Madura, proses pembelajaran Islam di langghâr cukup unik karena tidak hanya mengajarkan para santrinya membaca Al Qur-an, namun juga terdapat upaya melestarikan budaya tradisional seperti belajar mamaca. Mamaca adalah seni tradisi lisan warisan leluhur masyarakat Madura yang bersumber dari ajaran Islam Wali Sanga. Terminologi mamaca berasal dari bahasa Madura yang berarti membaca (Ahmad, 2017, p. 1). Secara teknis, kesenian mamaca merupakan suatu kegiatan membaca teks berupa kisahkisah bernuansa Islam yang ditulis dengan menggunakan aksara Arab Melayu terkadang juga Arab pegon, dengan cara ditembangkan/dilagukan (dinyanyikan), kemudian dijelaskan artinya (è tegghessi). Bahasa yang digunakan dalam aksara Arab tersebut bukanlah bahasa Arab melainkan bahasa Jawa Kromo, terkadang juga ditemukan bahasa campuran Jawa Madura. 
Mamaca di Madura adalah bentuk lain dari macopat di Jawa. Pembedanya ialah pada peran tokang tegghes (juru ulas). Di Madura pembacaan mamaca membutuhkan dua peran yang penting dalam pertunjukan yakni tokang maca (pembaca) dan tokang tegghes (penerjemah/juru ulas). Tokang maca memiliki peran membaca teks cerita dengan cara menyanyikan dalam bentuk tembang dari bait per bait, kamudian dilanjutkan oleh tokang tegghes yang tugasnya menginterpretasi bacaan tersebut ke dalam bahasa Madura (Hidayatullah, 2018a, p. 11). Mamaca lahir dari kebudayaan Islam yang masuk ke wilayah Madura melalui syiar Wali Sanga.

Sebelum mamaca berkembang di Sumenep, sebetulnya masyarakat di Sumenep sudah mengenal tradisi macopat Jawa yang dibawa oleh kerajaan Jawa ketika berbubungan secara politik dengan keraton Sumenep. Dalam naskah Babad Madura diilustrasikan bahwa gamelan dulunya merupakan wahana yang penting dalam acara iring-iringan prajurit keraton Surakarta dalam rangka penjemputan calon permaisuri dari Madura (Sastroyatmo, 1981; Setiawan, 2018 , p. 1). Hubungan politis yang erat antara raja Jawa dan Madura di masa silam turut mempengaruhi kebudayaan di Madura, beberapa aspek kesenian Jawa akhirnya diadaptasi oleh masyarakat Madura seperti musik gamelan dan tembang macopat. Kesenian tersebut pada akhirnya menjadi jalan yang dipilih oleh para wali dan ulama dalam proses mengislamkan Madura. KH. Ismail menjelaskan bahwa sebelum masuk Islam macopat sudah ada di Sumenep, kemudian Islam masuk salah satunya melalui jalur kesenian macopat, karena dianggap lebih mudah menarik perhatian masyarakat (Ismail, Komunikasi Pribadi, 30 Juli 2019). Kesenian macopat yang tadinya mengandung nilai-nilai spiritualitas Hindu, kemudian diadaptasi dan diganti dengan nilai-nilai Islam, sehingga salah satu proses islamisasi yang terjadi di Madura berlangsung melalui jalur kesenian dan bukan jalur konfliktual. Menurut KH. Ismail, mamaca berisi tentang makna-makna kehidupan dan pedoman bagi setiap manusia dalam menjalani kehidupan (Ismail, Komunikasi Pribadi, 30 Juli 2019). Mamaca bukan hanya perkara kesenian yang menghibur tetapi lebih pada kesenian yang membutuhkan perenungan batin, dalam ungkapan bahasa Madura acap kali disebut sebagai proses ngajhi $a b \hat{a}^{\prime}$ (mengenali diri). Ihwal ini mernarik untuk diuraikan dalam sebuah kajian, tentang bagaimana proses seorang Madura mengenali jatidirinya dan berproses menjadi manusia Madura lewat peristiwa pertunjukan mamaca.

\section{Teks Mamaca Dan Cara Pergelaran}

Mamaca pada dasaranya merupakan seni tradisi yang menonjolkan aspek suara (vokal). Kendati pertunjukan mamaca dihadirkan dalam ruang pertunjukan (audio-visual), namun sebetulnya yang paling ditonjolkan bukanlah aspek visual, karena tidak ada aspek penyutradaraan tubuh, tidak ada gerak, tidak ada dekorasi, panggung ataupun aksesoris lainnya. Ketiadaan unsur yang bisa ditonton memunculkan konsekuensi estetis, yakni pertunjukannya akan bergantung pada kekuatan imajinasi yang diaktualisasikan oleh gaya tutur tokang maca dan tokang tegghes (Hidayatullah, 2018a, p. 11).

Bentuk pergelaran mamaca terdiri atas pelbagai macam jenis dan variasi, biasanya menyesuaikan dengan kebutuhan dan konteksnya. Jenis pergelaran yang sering kali ditampilkan yaitu, pergelaran dalam konteks sakral seperti pada acara rokat pandhâbâa (ruwat anak pandawa), mèrèt kandung (selamatan kehamilan), molotan (maulud Nabi) dan Isra' Mi'raj; serta pagelaran dalam konteks profan/hiburan seperti pada acara arisan/kompolan mamaca dan pertunjukan pariwisata. Semua pergelaran mamaca merujuk pada sumber teks primer yaitu kitab mamaca. Konteks pada pagelaran mamaca akan menen- 
tukan kitab/ cerita apa yang dianggap pantas/ layak untuk dibacakan dalam pergelaran tersebut. Pada konteks rokat pandhâba teks yang akan dipergelarkan bersumber dari cerita yang diambil dari kitab pandhâbâ; pada konteks selamatan mèrèt kandung yang dipergelarkan bersumber dari cerita yang diambil dari kitab Nur Bhuwwât, serta pada konteks arisan/kompolan mamaca teks yang dipergelarkan biasanya lebih dinamis tergantung kesepakatan anggota misalnya kisah Juhar Manik.

Menurut KH Ismail, teks mamaca yang berada di Sumenep cukup banyak jumlahnya bisa mencapai lima puluhan lebih, hanya saja saat ini tidak semua teks tersebut ditampilkan ke publik, lebih lagi karena naskahnya sudah banyak yang hilang. Lebih lanjut, KH Ismail menyebutkan pelbagai teks yang masih sering ia pergelarkan kepada masyarakat Sumenep (Ismail, Komunikasi Pribadi, 30 Juli 2019). Berdasarkan sejarahnya ia membagi klasifikasi kitab-kitab yang diturunkan oleh Wali Sanga dan para ulama di Madura dengan kitab hasil adaptasi dan bersumber dari kebudayaan Hindu dan Timur Tengah. Kitab-kitab yang diturunkan oleh para Wali Sanga dan para Ulama di Madura antara lain yaitu 1). Qisosul Anbiya Wal Auliya (kisahnya para Nabi dan para Wali); 2). Nur Bhuwwat (kisah lahirnya Nabi Muhammad); 3). Isra' Mi'raj; 4). Kisah Nabi Yusuf; 5). Candra Jagad (syari'at, tarekat, ma'rifat dan ilmu hikmah); 6) Bahrul Qolbi (saghâra atè/lautan hati) ditulis oleh Wali Sumenep Kiai Khatib Sendang, putra Pangeran Katandur; 7). Al Hikam (urusan kaulâ gustè/hubungan antara hamba dan Tuhan-nya); 8). Murtasiah (hubungan pria dan wanita yang berisi tuntunan agama); 9). Padma Rasa - Padma Raga (hubungan perasaan hamba dengan Allah, hubungan jasad dengan rasa); 10). Iman Jati (Iman yang sebenar-benarnya); 11). Babad Sumenep (sejarah Sumenep); 12) Babad Madhurâ (sejarah Madura); dan lain sebagainya. Klasifikasi yang kedua yakni kitab-kitab yang diadaptasi dari kebudayaan Hindu dan lainnya yaitu 1). Pandhâbâ Lèma' (mahabarata); 2). Butoh dadi Ratu; 3). Sembadra Tundung; 4). Juhar Manik; dan lain sebagainya.

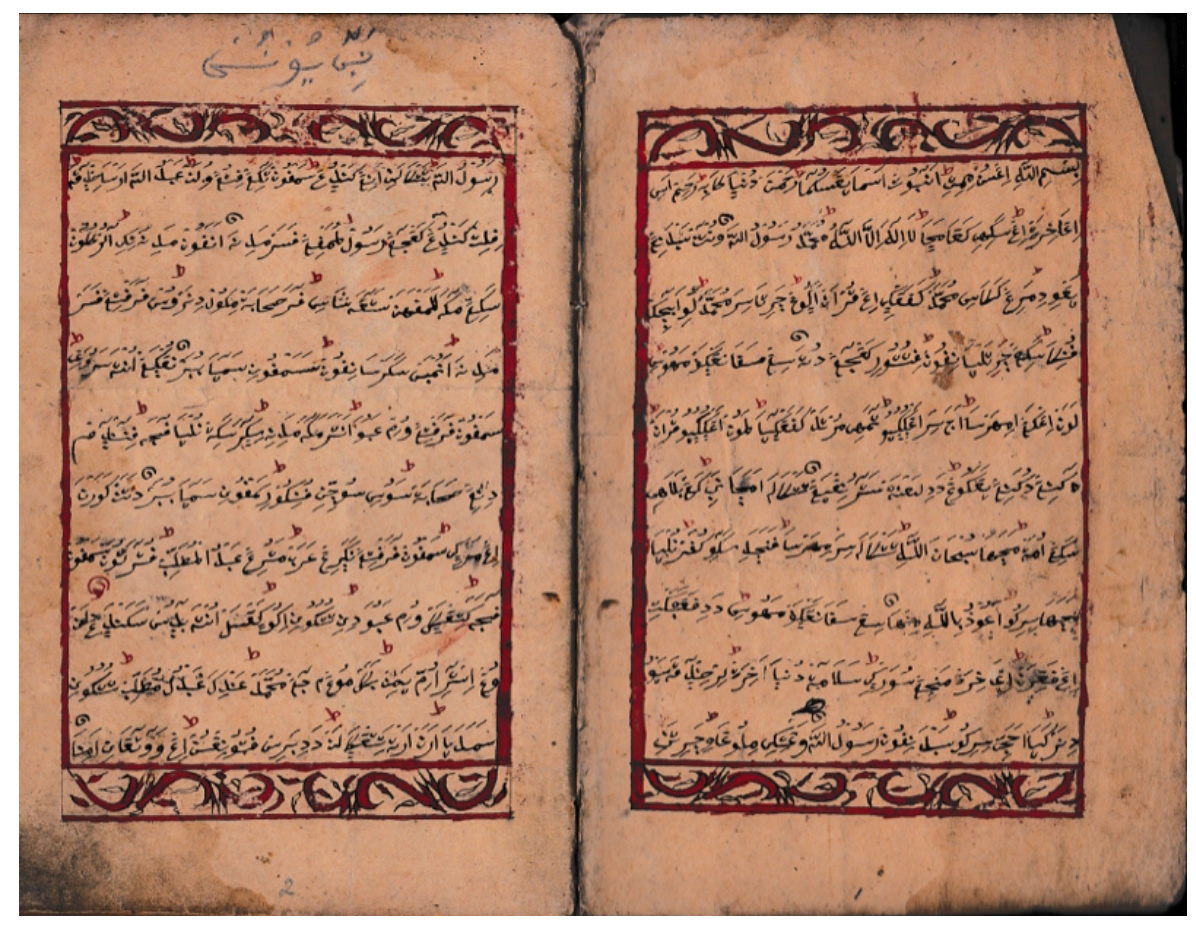

Gambar 3. Teks Kitab Mamaca Menggunakan Aksara Arab Sumber: Dokumen Pribadi 
Penyajian mamaca di Sumenep juga memiliki ragam variasi diantaranya ada yang hanya terdiri atas tokang maca dan tokang tegghes, ada yang ditambahkan dengan iringan solèng (suling Madura), dan ada juga yang diiringi oleh seperangkat gamelan Madura lengkap (disebut dhir-ghendhirân). Pemilihan jenis penyajian biasanya tergantung kebutuhan pertunjukan dan kemampuan penyelenggara pergelaran. Pergelaran dengan menggunakan format musik gamelan tentu saja membutuhkan biaya yang lebih besar dibanding dengan hanya menggunakan dua pelaku tokang maca dan tokang tegghes. Perlu dijelaskan bahwa tidak semua repertoar mamaca dapat diiringi oleh suling dan gamelan. Ada beberapa repertoar yang tidak boleh diiringi oleh instrumen musik apapun, dan hanya boleh menggunakan peran tokang maca dan tokang tegghes saja. Repertoar yang tidak boleh diiringi oleh instrumen musik diantaranya adalah beberapa kisah yang diklasifikasikan dalam kategori kitab yang dianggap sakral dan diturunkan oleh para Wali Sanga, seperti Qisosul Anbiya Wal Auliya, Nur Bhuwwat, dan Al Hikam. Menurut KH. Ismail pelarangan menggunakan instrumen musik bukan karena persoalan dosa atau tidak, namun lebih pada etika dan kebutuhan penghayatan. Pada cerita tersebut akan lebih bijak jika tidak diberi tambahan instrumentasi musik apapun supaya menimbulkan kesan yang lebih khusuk, intim dan mampu mengantarkan pada kedalaman rasa (Ismail, Komunikasi Pribadi, 30 Juli 2019). Selain itu menggunakan instrumen musik dianggap kurang cocok/pantas jika digunakan pada konteks ceritanya. Selebihnya instrumen musik dapat bebas dimainkan pada konteks cerita selain yang disebutkan di atas.

Penggunaan instrumen suling mempunyai fungsi untuk membantu tokang maca dalam menentukan awalan nada pada sebuah tembang yang akan dinyanyikan, bunyi suling akan menjadi barometer melodi vokalnya. Pada bagian tengah suling akan mengisi filler atau isianisian melodi pada jeda kalimat. Suara tumpang tindih antara tokang maca dan pemain suling akan membentuk harmonisasi yang indah dan intim. Sementara penggunaan set gamelan menjadi pengiring dalam pembacaan mamaca.

Berdasarkan moda pergelarannya (mode of presentastion) yang paling umum, mamaca dibagi atas dua bentuk klasifikasi pertunjukan. Penulis meminjam konsep yang digunakan oleh Lono Simatupang dalam merumuskan moda pagelaran pada reyog Ponorogo yaitu moda presentasional, dan moda partisipatoris (Simatupang, 2019, p. 157). Kategori presentasional mengarah pada pagelaran mamaca yang diarahkan untuk kepentingan pertunjukan yang "tertib", atau dengan kata lain sengaja dikonsep oleh pihak penyelenggara (biasanya pemerintah) untuk kebutuhan festival budaya, penyambutan tamu dan acara-acara formal. Kategori partisipatoris merujuk pada pergelaran mamaca yang tumbuh di realitas masyarakat Sumenep, yang sifatnya lebih bebas, improvisatoris, dinamis dan terbuka.

Kategori presentasional umumnya bersifat kaku, lebih menekankan pada aspek 'kegagahan estetik', biasanya dibumbuhi dengan teatrikal, kostum yang menarik, tampil di atas panggung dan pernak-pernik pertunjukan yang lainnya. Pada kategori presentasional, pagelaran mamaca tidak begitu memperhatikan aspek isi dan kedalaman syair teks, namun hanya sebatas mempresentasikan keindahan vokal. Dalam format presentasional biasanya pertunjukannya singkat, dan hanya mengambil beberapa potongan cerita yang relevan dengan konteks kebutuhan panggung. Ihwal yang peling menonjol dari kategori ini ialah adanya pembatasan antara siapa yang tampil dan siapa yang menonton (mendengarkan). Batas itu ditegaskan oleh format pertunjukan yang dipisahkan oleh panggung. 
Kategori partisipatoris bersifat kebalikan dari kategori sebelumnya, pergelarannya selalu terbuka dan dinamis bahkan penuh dengan improvisasi. Perlu ditambahkan bahwa dalam konteks pergelaran mamaca, katgori partisipatoris masih dapat dibagi lagi berdasarkan bentuk penyajian pertunjukannya. Ada pertunjukan yang bersifat tanggapan/undangan dan arisan/kompolan. Pertunjukan tanggapan misalnya seperti dalam acara rokatan (ruwatan), pelaku seni mamaca diundang ke salah satu rumah dan diminta untuk mempergelarkan pertunjukan mamaca di sana. Dalam acara rokat, pergelaran dilaksanakan semalam suntuk, dimulai dari pembacaan kitab pandhâbâ hingga dilanjutkan dengan pembacaan kidung rokat dan ritual rokat di sepertiga malam. Format pertunjukan dibuat melingkar, saling menyimak, dan berhadap-hadapan sehingga interaksi antar anggota dapat terjalin. Tokang maca kadang kala memberikan kesempatan kepada anggota lainnya untuk bergiliran membaca kitab, sementara anggota yang lain tetap menyimak dengan seksama setiap bacaan yang dilagukan oleh tokang maca, sesekali akan membenarkan kalimat yang salah jika ada kesalahan.

Pertunjukan partisipatoris berikutnya ialah pertunjukan dalam acara arisan/kompolan. Kompolan adalah bentuk perkumpulan/paguyuban orang Madura khususnya para lelaki yang tergabung dalam satu hobi/aktivitas seperti kompolan mamaca (perkumpulan mamaca), kompolan yasinan (perkumpulan pengajian yasin), kompolan saronen (perkumpulan saronen), kompolan saramaan (perkumpulan pencak silat) dan lainnya. Kompolan memiliki banyak fungsi dalam kebudayaan Madura, salah satunya menjadi pelestari kesenian tradisional. Eksistensi kompolan memberikan kesempatan kepada seniman tradisi dan pelaku budaya untuk tetap mendapatkan panggungnya dan menyalurkan ekspresinya tanpa harus menunggu tanggapan. Pagelaran mamaca dalam konteks kompolan berbeda dari pagelaran mamaca dalam konteks tanggapan. Dalam kompolan format pertunjukannya bebas, cerita yang akan dibacakan juga bebas tergantung kesepakatan anggotanya. Durasi pergelarannya tidak sampai semalam suntuk, umumnya berakhir sekitar pukul 12 malam hingga 1 dini hari. Partisipasi setiap anggota lebih aktif karena rata-rata anggota yang hadir dalam kompolan adalah para seniman, budayawan, dan orang-orang yang punya perhatian lebih pada kesenian mamaca. Setiap anggota diberi kesempatan untuk membaca teks mamaca di hadapan anggota yang lain.

Penjelasan mendalam tentang modus partisipatoris pergelaran mamaca pada konteks kompolan/arisan serta menguraikan persoalan tentang bagaimana orang Madura memaknai peristiwa pergelaran mamaca, telah dibahas sebelumnya pada bab hasil.

\section{Kesimpulan}

Mamaca adalah tradisi lisan masyarkat Madura yang diwariskan oleh para leluhur dan Wali dalam upaya mengislamkan pulau Jawa dan Madura. Tradisi mamaca hingga saat ini masih dilestarikan oleh masyarakt Madura karena dianggap memiliki nilai-nilai sejarah dan budaya yang tinggi. Sebagai media, mamaca merupakan jalan yang dipilih oleh para Wali guna menyebarkan syiar Islam di Sumenep Madura. la juga menjadi media pendidikan kultural yang efektif dalam mengembangkan karakter budaya pada masyarakat Madura di Sumenep. Teks mamaca terdiri atas pelbagai jenis, antara lain teks mamaca yang berasal dan diturunkan oleh para Wali Sanga dan ulama di Sumenep, serta teks mamaca yang dikembangkan dari hasil adaptasi budaya India dan Timur-Tengah. Berdasarkan moda pergelarannya, mamaca terbagi atas dua jenis yakni mamaca dalam moda pergelaran presentasional dan moda pergelaran partisipatoris. Moda pergelaran presentasional yaitu moda pergelaran yang menitikberatkan 
pada eksplorasi estetis dan memiliki sifat yang kaku dan tertutup seperti pergelaran mamaca pada festival budaya, sementara moda pergelaran partisipatoris lebih menitkberatkan pada kebebasan bentuk dan cenderung bersifat improvisatoris, terbuka dan dinamis seperti pergelaran mamaca pada konteks kompolan mamaca.

Hasil telaah atas pergerlaran mamaca dalam konteks moda partisipatoris pada pergelaran kompolan mamaca di Desa Kebundadap Barat, Saronggi, Sumenep dapat dirumuskan bahwa, pada dasaranya pergelaran mamaca masyarakat Madura di Sumenep merupakan sebuah jalan atau laku yang mengarah pada pembentukan karakter manusia Madura. Ihwal ini memberikan sudut pandang yang lain bahkan bertolak belakang dari stereotip tentang orang Madura yang muncul dari luar masyarakat Madura. Pandangan tentang orang Madura yang kasar, keras, jahat, bahkan udik, pada kenyataannya tidak tercermin pada pergelaran mamaca. Stereotip tersebut hanyalah pandangan yang parsial yang digeneralisir dan terkesan semena-mena. Melalui pagelaran mamaca dapat dipahami bahwa masyarakat Madura memiliki pandangan hidup dan karakter kepribadian yang luhur. Menjadi manusia Madura adalah sebuah proses yang harus ditempuh melalui jalan kebijaksanaan, dengan mewujudkan sikap yang menjunjung nilai tatakrama, sopan santun (adhâb), gotong royong, inklusif, apresiatif, rendah hati, mampu mengendalikan diri, mampu mengenali siapa dirinya (ngajhi abâ'), menjaga kehormatan, serta mampu menyebarkan kebaikan terhadap sesamanya.

\section{Referensi}

Ahimsa-Putra, H. S. (2015). Seni Tradisi, Jatidiri dan strategi kebudayaan. Jurnal IImu Sosial Mamangan.

Ahmad, R. (2017). Sepenggal Kearifan Bondowoso: Tradisi Mamaca Madura Parry - Lord's Perspective. Yogyakarta: Diandra Kreatif.

Bouvier, H. (2002). Lèbur!: Seni Musik dan Pertunjukan dalam Masyarakat Madura. Jakarta: Yayasan Obor Indonesia.

Hidayatullah, P. (2015). Upacara Seni Hodo Sebagai Ritual Kesuburan Masyarakat Dukuh Pariopo Situbondo. In International Conference on Nusantara Philosophy (pp. 459-471). Yogyakarta: Fakultas Fllsafat, Universitas Gadjah Mada.

Hidayatullah, P. (2018a). Mamaca: Sastra Lisan Masyarakat Madura. Buletin Sastra Dewan Kesenian Jember.

Hidayatullah, P. (2018b). Pengamalam Relijiusitas dalam Teater Tradisional Masyarakat Madura di Situbondo. Patrawidya.

Permanasari, Alis Triena; Setian, D. D. R. S. (2020). KESENIAN GENDREH: BENTUK DAN RESPON ESTETIS POLA TABUH ALU - LISUNG DI KAMPUNG BOJONG RANGKASBITUNG. Musikolastika, 2(2).

Retsikas, K. (2007). The Power of the Senses Ethnicity, History and Embodiment in East Java, Indonesia. Jurnal Indonesia and the Malay World, 35(102).

Rifai, M. A. (2007). Manusia Madura: Pembawaan, Prilaku, Etos Kerja, Penampilan, dan Pandangan Hidupnya seperti Dicitrakan Peribahasanya. Yogyakarta: Pilar Media.

Sastroyatmo, M. (Ed.). (1981). Babad Madura. Jakarta: Depdikbud, Proyek Penerbitan Buku Sastra Indonesia dan Daerah. 
Setiawan, A. (2018). Arkeologi Gamelan di Sumenep: Dari Imaji Masyarakat Akar Rumput tentang Gamelan Hingga Penelusuran Gamelan Langka Dengan Berbagai Problematiknya. Surakarta.

Simatupang, G. R. L. L. (2019). Play and Display: Dua Moda Pergelaran Reyog Ponorogo di Jawa Timur. Yogyakarta: Porgram Studi Pengkajian Seni Pertunjukan dan Seni Rupa, Universitas Gadjah Mada Yogyakarta.

Sofyan, A. (2009). Morfologi Bahasa Madura Dialek Sumenep. Universitas Gadjah Mada.

Walidaini, B. (2020). ANALISIS TEKSTUAL KOYUNBABA KARYA CARLO DOMENICONI: BENTUK DAN STRUKTUR BAGIAN I MODERATO. Musikolastika, 2(2).

Wiyata, L. (2013). Mencari Madura. Jakarta: Bidik-Phronesis Publishing.

Yoandinas, M., Hidayatullah, P., Farhan, M., Imron, M., \& Martiningsih, T. W. (2020). Tatèngghun: Realitas, Pengalaman dan Ekspresi Seni di Situbondo. (M. Yoandinas, Ed.). Situbondo: Bashish Publishing. 